SJîñm Jurnal

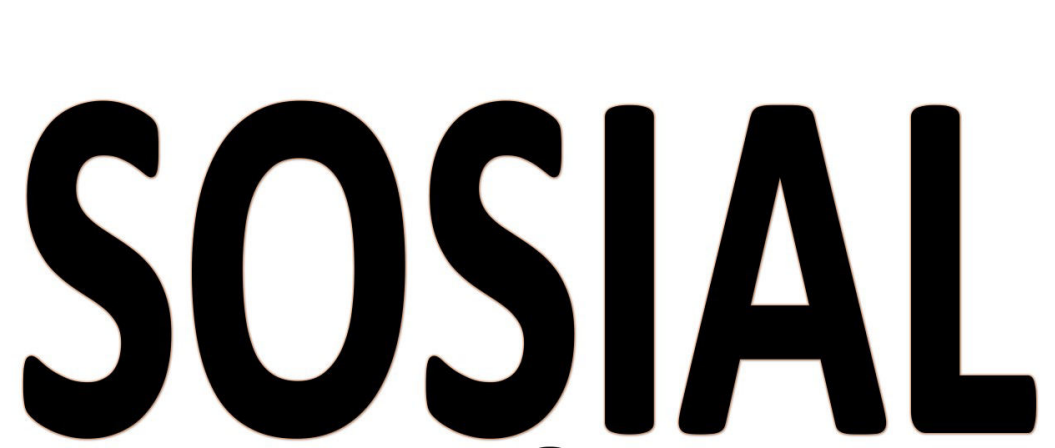

P-ISSN: 2356-1459 E-ISSN: 2654-9050 Vol. 7 No. 6 (2020)
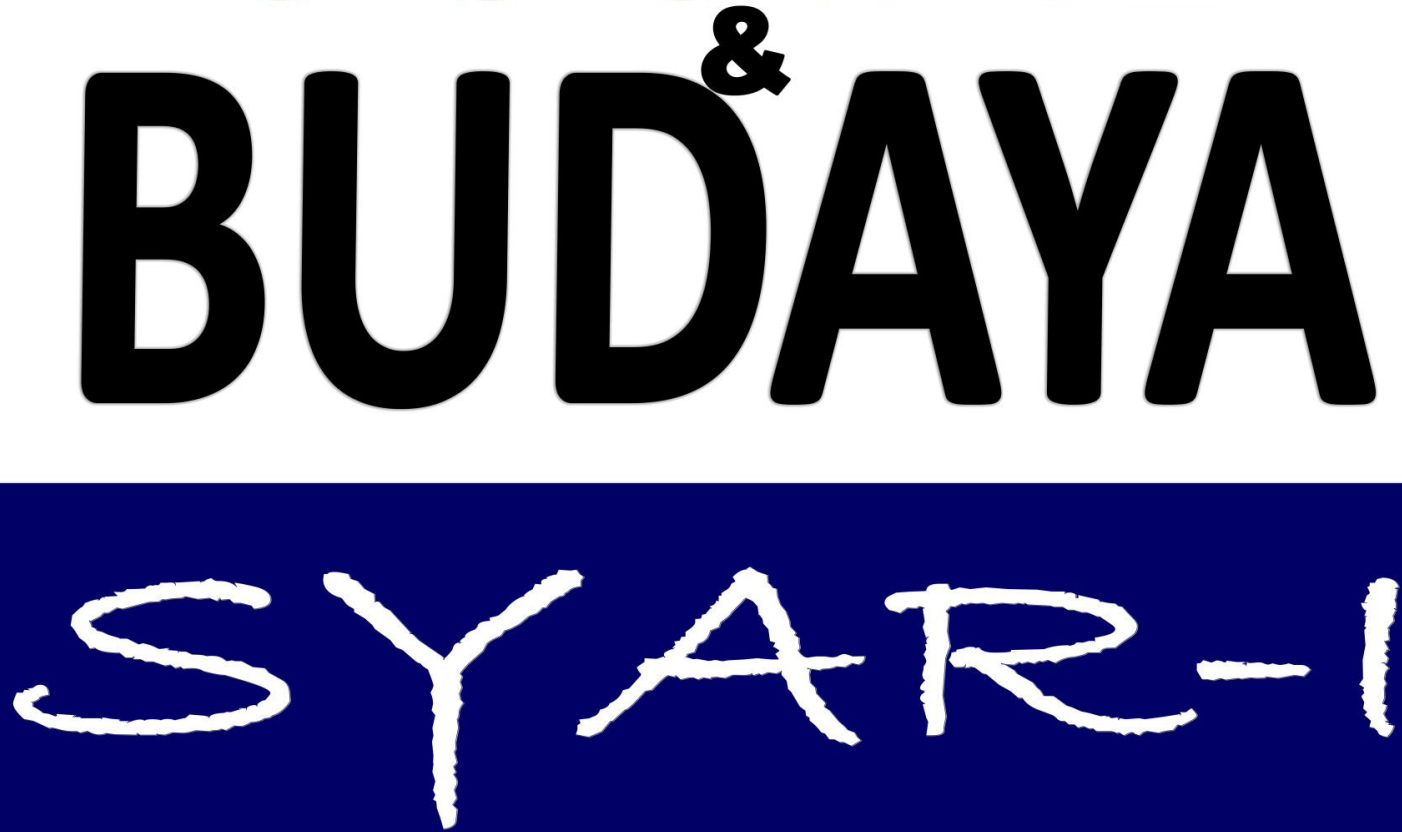

Bersama Melawan Virus Covid 19 di Indonesia

Syafrida \& Ralang Hartati

Optimalisasi Kebijakan Pemerintah dalam penanganan Covid-19 terhadap Masyarakat Indonesia Imas Novita Juaningsih, Yosua Consuello, Ahmad Tarmidzi \& Dzakwan Nurırfan

Kebijakan Pemberian Insentif Pada Tenaga Medis Virus Corona Covid-19 Pendekatan Maslahah Harisah

Budaya Media Sosial, Edukasi Masyarakat, dan Pandemi COVID-19

Muchammad Bayu Tejo Sampurno, Tri Cahyo Kusumandyoko \& Muh Ariffudin Islam

Covid-19 dan Hak Masyarakat atas Kesehatan

Siti Nurhalimah

Wabah Corona Virus Disease (Covid 19) Dalam Pandangan Islam

Eman Supriatna

Virus Corona Dampak dari Makanan yang tidak Halal

Faiqatul Husna 
SALAM; Jurnal Sosial \& Budaya Syar-i

FSH UIN Syarif Hidayatullah Jakarta

Vol. 7 No. 6 (2020), pp. 565-580, DOI: 10.15408/sjsbs.v7i6.15318

\title{
Virus Corona Dampak dari Makanan yang tidak Halal*
}

\author{
Faiqatul Husna ${ }^{1}$ \\ Institut Agama Islam Shalahuddin Al Ayubi (INISA) Tambun Bekasi \\ do: \\ 10.15408/sjsbs.v7i6.15318
}

\begin{abstract}
Alquran and Hadith have arranged halal and haram food. Obedience not to consume illicit food is believed to contain wisdom and goodness for Muslims. This research will discuss the impact of food that is not halal and have a bad influence on human health and society in general. Referring to the main sources of Islamic law, namely the Koran and Hadith regarding the urgency of halal, haram, and syubhat, and the purpose of prohibiting food. Based on the latest research on forbidden foods found many causes that are indeed unfit for consumption and can endanger human health such as the presence of harmful bacteria in the carcass, dangerous compounds in the blood, parasitic diseases in pigs, organ damage due to consumption of khamr and also the danger of eating prohibited animals by God such as eating bats, snakes, rats impact on the occurrence of a disease outbreak that spread very quickly precisely at the end of 2019 namely COVID-19 or known as the corona virus outbreak. The virus that first spread in the Wuhan region in China has become a global problem for all corners of the world.
\end{abstract}

Keywords: Covid-19, Haram Halal, Food

\begin{abstract}
Abstrak
Alquran dan Hadis telah mengatur makanan halal dan haram. Mentaati larangan untuk tidak mengkonsumsi makanan yang haram diyakini mengandung hikmah dan kebaikan bagi umat Islam. Peneliti kali ini akan membahas dampak makanan yang tidak halal dan memberikan pengaruh buruk bagi kesehatan manusia secara pribadi dan masyarakat secara umum. Merujuk pada sumber utama hukum Islam yakni Alquran dan Hadis mengenai urgensi hukum halal, haram, dan syubhat, serta tujuan diharamkannya makanan. Berdasarkan penelitian terkini pada makanan yang diharamkan ditemukan banyak sebab yang memang tidak layak untuk dikonsumsi dan dapat membahayakan kesehatan manusia seperti adanya bakteri berbahaya pada bangkai, senyawa berbahaya pada darah, penyakit parasit pada babi, kerusakan organ akibat konsumsi khamr dan serta bahaya memakan hewan yang dilarang oleh Allah seperti memakan kelelawar, ular, tikus berimbas pada terjadinya wabah penyakit yang merebak dengan sangat cepat tepatnya akhir tahun 2019 yaitu COVID-19 atau yang dikenal sebagai wabah virus corona. Virus yang pertama kali mewabah dari wilayah Wuhan di China sehingga menjadi permasalahan global bagi seluruh penjuru dunia.
\end{abstract}

Kata kunci: Covid-19, Halal Haram, Makanan

${ }^{*}$ Diterima: 11 April 2020, Revisi: 28 Mei 2020, Diterbitkan 31 Mei 2020.

${ }^{1}$ Faiqatul Husna adalah Dosen tetap pada Institut Agama Islam Shalahuddin Al Ayubi (INISA) Tambun Bekasi Jawa Barat. 


\section{Pendahuluan}

Islam merupakan agama yang mengatur segala sendi kehidupan manusia dari seluruh aspeknya. Salah satunya mengenai pemenuhan kebutuhan akan makanan. Selain mengenai faktor rasa, gizi, kebersihan dan keamanan suatu makanan, terdapat aspek lain yang tidak kalah penting yaitu status halal dan haram makanan. Islam memberikan perhatian yang sangat tinggi terhadap makanan halal, haram, atau syubhat (meragukan). Memperhatikan sumber makanan, kebersihan, cara pengolahan, penyajian, sampai cara membuang sisa makanan. ${ }^{2}$ Karena dalam ketentuan tersebut, terkandung nilai spiritual serta mencerminkan keluhuran akhlak seseorang.

Pada dasarnya segala makanan dan minuman yang berada di bumi adalah halal kecuali ada dalil yang mengharamkannya. Wilayah keharaman sangat sempit jika dibandingkan dengan wilayah kehalalan. Sehingga ketika tidak ada dalil yang mengharamkan atau menghalalkan maka kembali pada hukum asal yaitu mubah atau boleh. Dahulu, ketika ayat Alquran turun dengan membawa perintah yang berisi larangan mengonsumsi makanan haram dan kewajiban mengonsumsi yang halal, umat Islam menaati hal tersebut atas dasar keimanan dan ketaatan.

\section{Analisis dan Pembahasan}

\section{Asal Muasal Virus Corona}

Nama virus corona berasal dari Bahasa latin "corona" dan Yunani "korone" yang artinya adalah mahkota atau lingkaran cahaya, penamaan ini memang tak lepas dari wujud khas virus itu, yang memiliki pinggiran permukaan yang bulat dan besar, penampilan yang mengingatkan pada "corona matahari." Bentuk ini tercipta oleh peplomer viral spike yang merupakan protein yang mengisi permukaan virus.

Corona virus (CoV) adalah keluarga besar virus yang menyebabkan penyakit mulai dari gejala ringan sampai berat. Ada setidaknya dua jenis coronavirus yang diketahui menyebabkan penyakit yang dapat menimbulkan gejala berat seperti Middle East Respiratory Syndrome (MERS-CoV) dan Severe Acute Respiratory Syndrome (SARS-CoV). Novel coronavirus (2019- $\mathrm{nCoV}$ ) adalah virus jenis baru yang belum pernah diidentifikasi sebelumnya pada manusia. Virus corona adalah zoonosis (ditularkan antara hewan dan manusia). Penelitian menyebutkan bahwa SARS-CoV ditransmisikan dari kucing luwak (civet cats) ke manusia dan MERS-CoV dari unta ke manusia. Beberapa coronavirus yang dikenal beredar pada hewan namun belum terbukti menginfeksi manusia.

Pada 31 Desember 2019, WHO China Country Office melaporkan kasus pneumonia yang tidak diketahui etiologinya di Kota Wuhan, Provinsi Hubei, Cina. Pada tanggal 7 Januari 2020, Cina mengidentifikasi pneumonia yang tidak diketahui etiologinya tersebut sebagai jenis baru coronavirus (novel coronavirus, 2019-nCoV). Penambahan jumlah kasus 2019-nCoV berlangsung cukup cepat dan sudah terjadi penyebaran ke luar wilayah Wuhan dan negara lain. Sampai dengan 26 Januari 2020,

2 Zulaekah S, Kusumawati Y. Halal dan haram makanan dalam islam. SUHUF, Vol. XVII, No. 01/Mei 2005: 25-35 
secara global 1.320 kasus konfim di 10 negara dg 41 kematian (CFR 3,1\%). Rincian China 1297 kasus konfirmasi (termasuk Hongkong, Taiwan, dan Macau) dengan 41 kematian (39 kematian di Provinsi Hubei, 1 kematian di Provinsi Hebei, 1 kematian di Provinsi Heilongjiang), Jepang (3 kasus), Thailand (4 kasus), Korea Selatan (2 kasus), Vietnam (2 kasus), Singapura (3 kasus), USA (2 kasus), Nepal (1 kasus), Perancis (3 kasus), Australia (3 kasus). Diantara kasus tersebut, sudah ada beberapa tenaga kesehatan yang dilaporkan terinfeksi. Sampai dengan 24 Januari 2020, WHO melaporkan bahwa penularan dari manusia ke manusia terbatas (pada kontak keluarga) telah dikonfirmasi di sebagian besar Kota Wuhan, China dan negara lain.

Manifestasi klinis biasanya muncul dalam 2 hari hingga 14 hari setelah paparan. Tanda dan gejala umum infeksi coronavirus antara lain gejala gangguan pernapasan akut seperti demam, batuk dan sesak napas. Pada kasus yang berat dapat menyebabkan pneumonia, sindrom pernapasan akut, gagal ginjal, dan bahkan kematian. Tanda-tanda dan gejala klinis yang dilaporkan sebagian besar adalah demam, dengan beberapa kasus mengalami kesulitan bernapas, dan hasil rontgen menunjukkan infiltrat Pedoman Kesiapsiagaan Menghadapi Infeksi Novel Coronavirus (2019-nCoV) 11 pneumonia luas di kedua paru-paru. Menurut hasil penyelidikan epidemiologi awal, sebagian besar kasus di Wuhan memiliki riwayat bekerja, menangani, atau pengunjung yang sering berkunjung ke Pasar Grosir Makanan Laut Huanan. Sampai saat ini, penyebab penularan masih belum diketahui secara pasti. Rekomendasi standar untuk mencegah penyebaran infeksi dengan mencuci tangan secara teratur, menerapkan etika batuk dan bersin, memasak daging dan telur sampai matang. Hindari kontak dekat dengan siapa pun yang menunjukkan gejala penyakit pernapasan seperti batuk dan bersin. ${ }^{3}$

Virus Corona ( $\underline{\text { Covid-19) }}$ disebut berawal dari konsumsi binatang yang dalam Islam bukan saja tidak halal tetapi juga tidak baik (tayyiban). Binatang-binatang tersebut seperti ular, tikus dan kelelawar, yang jelas-jelas dalam Islam diharamkan. Di mulai dari salah satu penduduk yang terinfeksi virus tersebut di kota Wuhan, Cina, virus itu kemudian menjalar orang-orang lain dengan sengat cepat. Islam sudah jauh-jauh hari melalui Alqurannya mengharuskan umat manusia untuk memakan makanan yang halal dan juga baik (tayyiban).

\section{Terminologi Halal}

Kata "halal" dan "haram" merupakan istilah Alquran dan ini digunakan dalam pelbagai tempat dengan konsep berbeda, dan sebagiannya berkaitan dengan makanan dan minuman. Kedua kata tersebut juga digunakan dalam Hadis Nabi Saw. Halal secara bahasa, menurut sebagian pendapat, berasal dari akar kata الحل الإباحة lyang artinya

\footnotetext{
${ }^{3}$ https://www.itb.ac.id/files/focus/2020-01-25PedomanKesiapsiagaanNovelCoronaVirus3.pdf
} 
sesuatu yang dibolehkan menurut syariat. ${ }^{4}$ Menurut Abû Ja'far al-Tabârî (224-310 H), lafaz halâl حلال berarti terlepas atau terbebas. ${ }^{5}$

Abû Muhammad al-Husayn ibn Mas'ûd al-Baghawî (436-510H) dari mazhab Syaf' $i$, berpendapat kata "halâl" berarti sesuatu yang dibolehkan oleh syariat karena baik. ${ }^{6}$ Muhammad ibn 'Ali al-Syawkânî (1759-1834 H) berpendapat, dinyatakan sebagai halal karena telah terurainya simpul tali atau ikatan larangan yang mencegah. ${ }^{7}$ Senada dengan pendapat al-Syawkânî (1759-1834 H). Dari kalangan ulama kontemporer, seperti Yusuf al-Qaradhawî, mendefiniskan halal sebagai sesuatu yang dengannya terurailah buhul yang membahayakan, dan Allah memperbolehkan untuk dikerjakan. ${ }^{8}$ Sementara 'Abd al-Rahmân ibn Nâshir ibn al-Sa'dî' ketika mendefinisikan kata "halâl" menyorotinya kepada bagaimana memperolehnya, bukan dengan cara ghashab, mencuri, dan bukan sebagai hasil muamalah yang haram atau berbentuk haram. ${ }^{9}$

Dari beberapa penjelasan tersebut di atas, dapat ditarik kesimpulan halal adalah sesuatu yang diperbolehkan oleh syariat untuk (i) dilakukan, (ii) digunakan, atau (iii) diusahakan, karena telah terurai tali atau ikatan yang mencegahnya atau unsur yang membahayakannya dengan disertai perhatian cara memperolehnya, bukan dengan hasil muamalah yang dilarang.

Tentang lafadz "thayyib" yang disebutkan pada Ayat Alquran yang menegaskan akan keharusan umat manusia mengkonsumi makanan halal serta baik. Sebagaimana dalam Surat al-Baqarah ayat 168:

"Hai sekalian manusia, makanlah yang halal lagi baik dari apa yang terdapat di bumi, dan janganlah kamu mengikuti langkah-langkah syaitan; karena Sesungguhnya syaitan itu adalah musuh yang nyata bagimu"(Q.S AlBaqarah: 168).10

Menurut Abu Ja'far Muhammad bin Jarir Ath-Thabari dalam kitab tafsirnya Tafsir Ath-Thabari mengatakan bahwa wahai sekalian manusia, makanlah apa yang Aku halalkan atas kalian lewat lisan RasulKu, dimana Aku menghalalkan bagi kalian apa yang kalian haramkan yaitu bahirah, saibah, washilah, dan haam ${ }^{11}$ dan mengharamkan

\footnotetext{
${ }^{4}$ Muhammad Rawas dan Muhammad Shadiq Qanaybi, Mu'jam Lughah al-Fuqaha, (Bayrût: Dâr alFikr, 1405H-1985M), Cet. I, h. 184

${ }^{5}$ Muhammad ibn Jarir ibn Yazid ibn Katsir ibn Ghalib AbunJa'far al-Tabari, Jami' al-Bayan fi Ta'wil al-Quran, di-tahqiq oleh Ahmad Muhammad Syakir, (Madinah: Muassasah al-Risalah, Malik Fahd, 2000), h.102.

${ }^{6}$ Abu Muhammad al-Husayn ibn Mas'ud al-Baghawi, Ma'alim Tanzal, (Dar Tibah, Majma' Malik Fahd, 1417 H-1997 M), Cet. IV, jilid I, h. 180.

${ }^{7}$ Imam al-Syawkani, Fath al-Qadir, (Bayrût: Dâr al-Ma'rifah, 2007), Cet. IV, h. 216.

8 Yûsuf al-Qaradhawi, Al-Halal wa al-Haram f al-Islam, terjemah Wahid Amadi dkk, Halal Haram dalam Islam, (Solo: Era Intermedia, 1424H-2003 M), Cet III, h. 31.

${ }^{9}$ Abd al-Rahman ibn Nashir ibn al-Sa'di, Taysir al-Karîm al-Rahmân Tafsîr Kalm al-Mannân, ditahqiq oleh 'Abd al-Rahmân ibn Ma'la al-Luwayhik, (Madinah: Mu'assasah al-Risâlah, Malik Fahd, 2000), Cet. I, h. 80.

${ }^{10}$ Departemen Agama RI, Al-Quran dan Terjemahnya, op.cit., h. 25

${ }^{11}$ Bahirah adalah unta betina yang telah beranak lima kali dan anak yang kelima itu jantan, lalu unta betina itu dibelah telinganya, dilepaskan, tidak boleh ditunggangi dan tidak boleh diambil air susunya. Saibah adalah unta betina yang dibiarkan pergi ke mana saja disebabkan suatu nadzar Washilah adalah seekor domba betina melahirkan anak kembar yang berdiri dari jantan dan betina maka yang jantan disebut washilah, tidak disembelih dan diserahkan kepada berhala.
} 
atas kalian bangkai, darah, daging babi dan daging yang disembelih bukan atas nama$\mathrm{Ku}$, dan tinggalkanlah langkah-langkah setan yang mencelakakan kalian, dan janganlah kalian mengikutinya sesungguhnya ia adalah musuh yang nyata bagi kalian, dimana ia enggan bersujud kepada bapak kalian Adam dan menggelincirnya dari menaati Allah sehingga diusir dari surga. Yang dimaksud dengan طييا حلال adalah halal mutlaq, suci, tidak najis dan tidak haram. Sedangkan yang dimaksud dengan خطو ات الثيطان merupakan perbuatan-perbuatan setan. ${ }^{12}$

Menurut Syaik Ahmad Syakir dalam kitab tafsirnya Tafsir Ibnu Katsir ayat diatas menjelaskan bahwa tidak ada Tuhan yang berhak disembah kecuali Dia, dan sesungguhnya hanya Dialah yang Esa dalam penciptaan. Dia adalah dzat yang memberi rezeki kepada seluruh mahkluk-Nya. Serta Dia juga telah memubahkan bagi mereka makanan yang halal dan baik dari Allah, yaitu baik pada dzatnya dan tidak membahayakan kesehatan tubuh dan akal. ${ }^{13}$ Sedangkan menurut Sayyid Qutub dalam kitab Tafsir Fi Zhilalil Quran bahwa ayat tersebut menjelaskan tentang makanan yang diperbolehkan atau yang halal dari apa-apa yang terdapat di bumi kecuali yang sedikit yang dilarang karena berkaitan dengan hal-hal yang membahayakan dan telah ditegaskan dalam nash syara' yaitu terkait dengan akidah, sekaligus bersesuaian dengan fitrah alam dan fitrah manusia. Karena Allah menciptakan apa yang ada di bumi bagi manusia. Oleh sebab itu, Allah menghalalkan apa yang ada di bumi tanpa ada pembatasan tentang halal ini kecuali masalah khusus yang berbahaya. Jadi keterangan tentang penghalalan dari Allah ini, manusia bisa menikmati dari apa-apa yang baik dan sesuai dengan fitrah manusia, tanpa harus menerima dengan kesulitan dan desakan. ${ }^{14}$

Menurut Hamka dalam Tafsir Al-Azhar bahwa ayat 168 ada hubungannya dengan ayat sebelumnya. Yaitu tentang kecurangan-kecurangan, penipuan dan melalui mata yang bodoh, banyak ataupun sedikit adalah hubungannya dengan perut asal berisi. Berapa perbuatan yang curang terjadi di atas dunia ini oleh karena mempertahankan syahwat perut. Maka, apabila manusia telah mengatur makan minumnya, dengan mencarinya dari yang halal, bukan dari penipuan, bukan dari korupsi, maka jiwa akan terpelihara dari kekasarannya. Dalam ayat ini menjelaskan tentang yang halal lagi baik. Makanan yang halal adalah lawan dari yang haram. Makanan yang haram telah pula disebutkan dalam Alquran yaitu yang tidak disembelih untuk berhala, daging babi, darah dan yang disembelih untuk berhala. ${ }^{15}$

Dijelaskan pula dalam Tafsir al-Misbah karya Quraish Shihab bahwasanya ajakan ayat diatas ditujukan bukan hanya kepada orang-orang beriman tetapi untuk seluruh manusia. Hal ini menunjukkan bahwa bumi disiapkan Allah untuk memonopoli hasil-hasilnya, baik kelompok kecil maupun besar, keluarga, suku, bangsa atau kawasan dengan merugikan yang lain, itu bertentangan dengan ketentuan Allah. Karena itu, semua manusia diajak untuk makan yang halal dan yang ada di bumi. Namun tidak semua yang ada di dunia otomatis halal dimakan atau digunakan. Seperti Allah

${ }^{12}$ Abu Ja'far Muhammad bin Jarir Ath-Thabari, Tafsir Ath-Thabari, (Jakarta: Pustaka Azzam, 2008),

${ }^{13}$ Syaikh Ahmad Syakir, Tafsir Ibnu Katsir,( Jakarta: Darus Sunnah, 2014), h. 459

${ }^{14}$ Sayyid Qutub, Tafsir fi Zhilalil Qureean, jilid I, (Jakarta: Gema Insani, 2000), h. 276

${ }^{15}$ HAMKA, Tafsir Al-Azhar, (Jakarta: Gema Insani, 2015), h. 307 
menciptakan ular berbisa, bukan untuk dimakan, tetapi bisanya untuk digunakan sebagai obat. Ada juga burung-burung yang diciptakan-Nya untuk memakan serangga yang merusak tanaman. Dengan demikian tidak semua yang ada di bumi menjadi makanan yang halal karena bukan semua yang diciptakan untuk dimakan manusia, walau semua untuk kepentingan manusia. Karena itu Allah memerintahkan kepada manusia untuk makan makanan yang halal. Makanan yang halal adalah makanan yang tidak haram, artinya makanan yang tidak dilarang oleh agama. Sedangkan Makanan yang haram ada dua macam yaitu haram karena dzatnya seperti: babi, dan darah, dan haram karena sesuatu bukan dzatnya, seperti makanan yang tidak diizinkan oleh pemiliknya untuk dimakan atau digunakan. Jadi yang dimaksud makanan yang halal adalah makanan yang bukan termasuk kedua macam itu. Selain itu, perlu digarisbawahi bahwa tidak semua makanan yang halal otomatis baik, karena yang dinamai halal terdiri dari empat macam: wajib, sunnah, mubah, dan makruh. Aktivitas pun demikian, ada aktivitas yang walaupun halal namun makruh atau sangat tidak disukai Allah, misalnya pemutusan hubungan. Selanjutnya, tidak semua yang halal sesuai dengan kondisi kesehatan tertentu, dan ada juga yang kurang baik untuknya, walau itu baik buat orang lain. Ada makanan yang halal, tidak bergizi, dan ketika itu ia menjadi kurang baik. ${ }^{16}$

Menurut hemat penulis, ada tiga hal yang perlu diperhatikan agar makanan yang dikonsumsi manusia benar-benar sesuai ajaran agama. Pertama, makanan yang Allah rizkikan; persoalan di sini berarti mengecualikan makanan yang didapat dari mencuri atau mengurangi timbangan dalam jual beli. Kedua, halal; pada kedua ini mengecualikan memakan binatang yang diharamkan, seperti anjing, babi, dan sesamanya. Dan ketiga, baik (tayyiban); makanan yang baik mengecualikan makanan yang pada dasarnya rizki dari Allah dan ia halal, namun sudah tidak layak konsumsi, seperti nasi basi dan sesamanya.

Penjelasan para mufasir Alquran atas ayat tersebut di atas cukup terang, bahwa memakan makanan yang halal dan baik adalah perintah agama, yang bukan saja akan memberi dampak kepada kebaikan agamanya, akan tetapi juga kebaikan kesehatannya. Memakan makanan tidak boleh asal memakan, tetapi harus pertimbangkan kepastian halal dan baiknya.

Pada kasus penyakit yang timbul dari virus Corona, jika kita timbang dengan penjelasan para mufasir atas ayat-ayat Alquran di atas, mungkin saja sebab dikarenakan adanya manusia yang serakah; memakan makanan yang tidak halal dan tidak baik. Atau, memakan makanan halal, akan tetapi tidak baik. Oleh karena itu Allah datangkan virus yang dapat menyerang kesehatan manusianya. Maka dari itu, umat manusia tidak boleh lagi mengkonsumsi makanan yang tidak halal dan tidak baik. Alquran sudah sejak 14 abad yang lalu memberi panduan yang cukup terang agar manusia tidak terjangkit penyakit, yaitu mengkonsumsi makanan halal lagi baik.

${ }^{16}$ M. Quraish Shihab, Tafsir Al-Misbah; Pesan, Kesan dan Keserasian al-Quran, (Jakarta: Lentera Hati, 2002), h. 456-457 


\section{Terminologi Haram}

Terminologi Haram Sebelum membahas tujuan dan hikmat penetapan halal dan haram, penting lebih dahulu menulis pengertian "haram". Dari sisi bahasa, haram adalah dilarang/terlarang atau tidak diizinkan. ${ }^{17}$ Dari sisi istilah, menurut Yûsuf alQarâdhawî haram sesuatu yang Allah melarang untuk dilakukan dengan larangan yang tegas, setiap orang yang menentangnya akan berhadapan dengan siksaan Allah di akhirat, bahkan terkadang ia juga terancam sanksi syariat di dunia. ${ }^{18}$

Peneliti menambahkan, keharaman itu ada dua macam yaitu karena disebabkan zatnya, yaitu jelek dan keji, lawan dari thayyib. Atau haram dikarenakan yang ditampakkannya, yaitu keharaman yang berkaitan dengan hak Allah atau hak hambaNya dan ini adalah lawannya halal. Penyebutan "haram" dengan perubahan bentuknya dari Alquran yang memiliki konteks dengan makanan, minuman dan pakaian terdapat pada surah al-Baqarah (2): 172-73, al-Mâ'idah (5): 3, 87, al-An'âm (6) 143, 144, 145, dan 146, al-A'râf (7): 32, 157, al-Nahl (16): 115, 116, 118.

Sumber Alquran dalam bentuk pengharaman, misalnya penetapan keharaman bangkai, darah, daging babi, dan sesuatu yang disembelih dengan menyebut nama selain Allah, pada surah al-Mâ'idah (3):

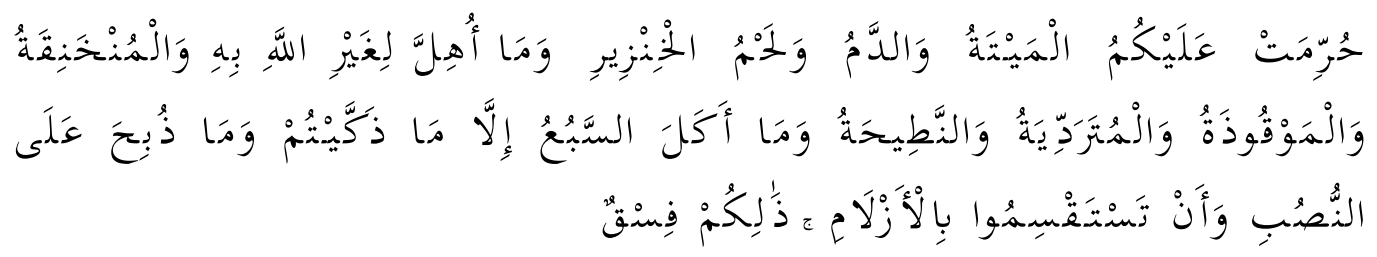

"Diharamkan bagimu (memakan) bangkai, darah, daging babi, (daging hewan) yang disembelih atas nama selain Allah, yang tercekik, yang terpukul, yang jatuh, yang ditanduk, dan diterkam binatang buas, kecuali yang sempat kamu menyembelihnya, dan (diharamkan bagimu) yang disembelih untuk berhala. Dan (diharamkan juga) mengundi nasib dengan anak panah, (mengundi nasib dengan anak panah itu) adalah kefasikan."

Al-Tabari menulis pandangan Abû Ja'far bahwa pada ayat tersebut menunjukkan Allah telah mengharamkan bangkai. ${ }^{19}$ Menurut al-Qardhawi wilayah keharaman dalam syariat Islam sangatlah sempit, sebaliknya, wilayah kehalalan terbentanglah sangat luas. Karena nas (nash) yang datang dengan pengharaman sedikit sekali jumlahnya. Selain itu, sesuatu yang tidak ada nas yang mengharamkan atau menghalalkannya, ia kembali kepada hukum asalnya, boleh. Ia berada dalam wilayah kemaafan Tuhan. ${ }^{20}$

Larangan keras memakan bangkai, darah, daging babi, dan binatang yang disembelih karena selain Allah dapat dipahami pada surah al-Mâ'idah(5):3, alAn’âm(6):14. Memang penghraman arak, tuak, dan khamar diterapkan secara bertahap

${ }_{17}$ Abu al-Sa'ud Muhammad ibn Muhammad ibn Musthafâ alImadî, Mufradât al-Qur'ân, versi Maktabah asy Syamilah, h. 315.

${ }^{18}$ Yusuf al-Qaradhawî, Al-Halal wa al-Haram fil-Islam, terjemah Wahid Amadi dkk, Halal Haram dalam Islam, h:31

${ }^{19}$ Muhammad ibn Jarir ibn Yazid ibn Katsir, Jami' al-Bayân fi Ta'wil al-Quran, h. 492.

${ }^{20}$ Yusuf al-Qaradhawi, Al-Halal wa al-Haram fil-Islam, h. 37 
setelah terbentuknya umat Muslim di Madinah. Dispensasi umum terhadap larangan dengan beberapa syarat. Dalam surat al-a'raf (7):157 melarang memakan hewan yang menjijikkan yang berbunyi:

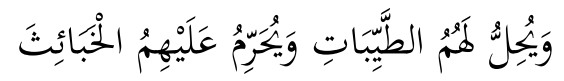

"Dan menghalalkan bagi mereka segala yang baik dan mengharamkan bagi mereka segala yang buruk. (QS. Al A'raaf: 157)"

Adapun pengharaman memakan hewan yang menjijikkan secara eksplisit tidak disebutkan secara rinci dalam alquran, namun ada hadist yang melarang untuk membunuh hewan yang menjijikkan, jika membunuhnya dilarang apalagi memakannya. Sebagaimana dalam sabda Nabi Muhammad SAW :

$$
\begin{aligned}
& \text { عن عَبد الله بن عَمْرو، أنه قال : لاَ تقتلوا الضفادع فإن نقيقها تسبيح ، ولا تقتلوا الحنفاش فإنه لما } \\
& \text { خرب بيت المقدس قال : يا رب سلطني على البحر حتى أغرقهم } 21
\end{aligned}
$$

Dari 'Abdullah bin 'Amru, ia berkata, "Janganlah kalian membunuh katak, karena suaranya adalah tasbiih. Jangan kalian pula membunuh kelelawar, karena ketika Baitul-Maqdis roboh ia berkata: 'Wahai Rabb, berikanlah kekuasaan padaku atas lautan hingga aku dapat menenggelamkan mereka" (HR. Al Baihaqi)

Imam Nawawi dalam Al-Majmu' Syarah Muhad zdzab menegaskan haramnya kelelawar menurut mazhab Syafi'i. Beliau menyatakan:

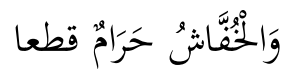

Artinya: "Kelelawar hukumnya haram secara meyakinkan" 22

\section{Terminologi Syubhat}

Syubhat adalah sesuatu yang tidak jelas kehalalan dan keharamannya karena banyak manusia yang tidak mengetahui hukumnya. Adapun ulama mereka dapat mengetahui hukum dari nas atau qiyâs atau sebagainya, apabila seseorang meragukan sesuatu apakah halal atau haram sementara tidak ada nas dan ijmak sebagai hasil ijtihad mujtahid lalu mendapatkan dalil syar'i-nya lalu dijumpainya halal maka ia menjadi halal, tetapi terkadang ada dalilnya, namun tidak tertutup kemungkinan keraguan (ihtimâl) yang jelas maka lebih utama bersikap wara' dengan meninggalkannya, karena sikap seperti ini merupakan pengamalan sabda Nabi Saw:

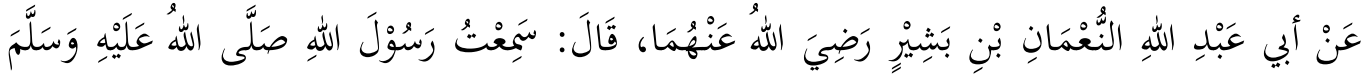

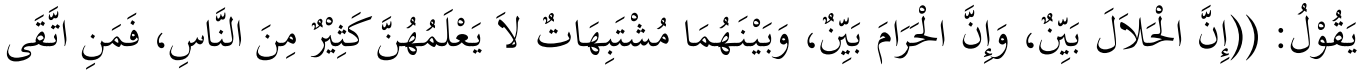

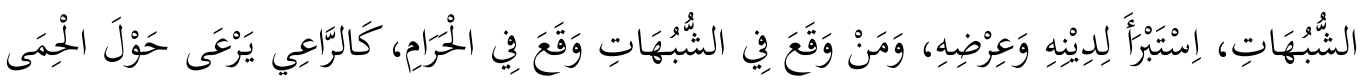

\footnotetext{
${ }^{21}$ Imam Baihaqi , Assunan ash-shoghir, (Beirut:Darul Fikr, 2000),jilid 4,h.59, no.3059

${ }^{22}$ Imam Nawawi, Al-Majmu' Syarah Al-Muhadzab, (Beirut:Darul Fikr,2000), juz 9, halaman 22.
} 


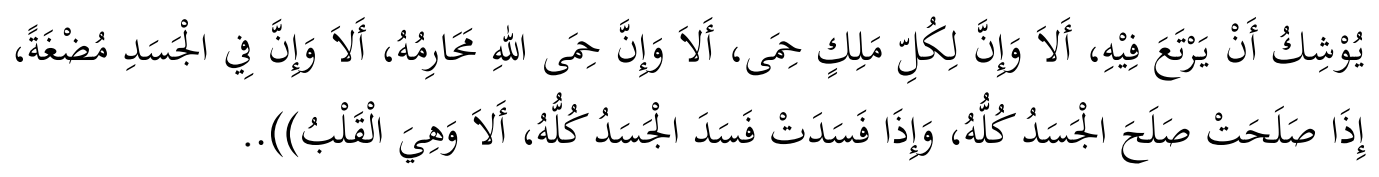

Dari Abu Abdillah an Nu'man bin Basyir Radhiyallahu 'anhuma, beliau berkata: Aku mendengar Rasulullah Shallallahu 'alaihi wa sallam bersabda: "Sesungguhnya yang halal itu jelas, dan yang haram itu jelas. Dan di antara keduanya terdapat perkaraperkara syubhat (samar, belum jelas) yang tidak diketahui oleh kebanyakan orang. Maka barangsiapa yang menjaga (dirinya) dari syubhat, ia telah berlepas diri (demi keselamatan) agama dan kehormatannya. Dan barangsiapa yang terjerumus ke dalam syubhat, ia pun terjerumus ke dalam (hal-hal yang) haram. Bagaikan seorang penggembala yang menggembalakan hewan ternaknya di sekitar kawasan terlarang, maka hampir-hampir (dikhawatirkan) akan memasukinya. Ketahuilah, sesungguhnya setiap penguasa (raja) memiliki kawasan terlarang. Ketahuilah, sesungguhnya kawasan terlarang Allah adalah hal-hal yang diharamkanNya. Ketahuilah, sesungguhnya di dalam tubuh terdapat segumpal daging. Apabila segumpal daging tersebut baik, (maka) baiklah seluruh tubuhnya. Dan apabila segumpal daging tersebut buruk, (maka) buruklah seluruh tubuhnya. Ketahuilah, segumpal daging itu adalah hati." ${ }^{23}$

\section{Tujuan Pengaturan Halal, Haram dan syubhat}

Ulama menegaskan bahwa hukum Islam diciptakan untuk mewujudkan kemaslahatan manusia di dunia dan akhirat. Kemaslahatan ada yang bersifat primer (dharûriyyah), sekunder (hajiyyah), dan ada yang bersifat tersier (tahsiniyyah), sebagaimana dinyatakan Imam al-Ghazalî dan al-Syâthibî. Menurut Imam alSyâthibî, tugas syariah berorientasi pada terwjudnya tujuan-tujuan kemanusiaan yang terdiri atas bagian primer (dharûriyyah), sekunder (hajiyyah), dan tersier (tahsiniyyah). Primer, artinya sesuatu yang harus ada guna terwujudnya kemaslahatan agama dan dunia. Apabila sesuatu itu hilang, kemaslahaan manusia akan sulit terwujud, bahkan akan menimbulkan kerusakan, kekacauan dan kehancuran.

Di sisi lain, kebahagiaan dan kenikmatan akan lenyap dan kerugian yang nyata akan muncul. Untuk menjaga hal tersebut diperlukan dua hal. Pertama, sesuatu yang dapat menjaga dan mengukuhkan pondasi dan kaidah syariat dan merupakan aspek utama untuk menjaga keberadaan syariat. Kedua, sesuatu yang dapat mencegah pelanggaran langsung atau tidak langsung terhadap syariat dan merupakan aspek untuk menghindari kepunahan syariat.

Perintah syariat bertujuan untuk menjaga kemaslahatan, ini dapat dipahami bahwa syariat bertujuan mencegah dan menghilangkan kerusakan-kerusakan. Prinsip ini ditegaskan dalam Hadis Nabi SAW:

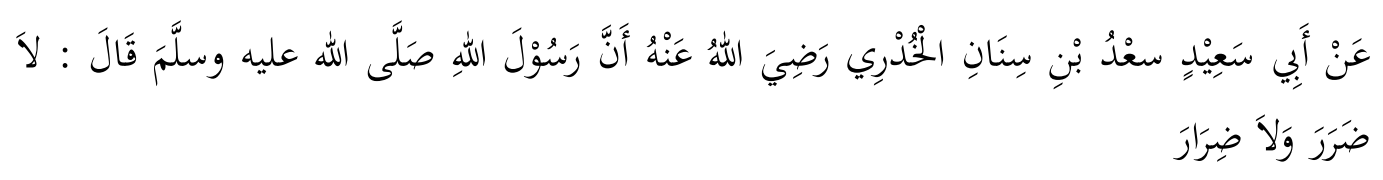

${ }^{23}$ Abu Zakariya Yahya bin Syaraf an-Nawawi ad-Dimasqi, Matan Arba'in Nawawi, (Surabaya: Pustaka Syabab,2007), h.12 


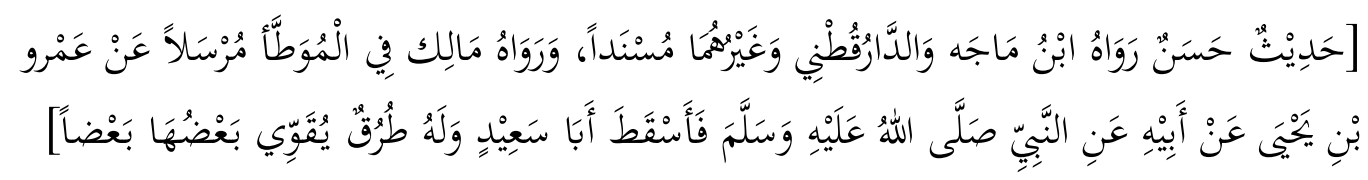

Dari Abu Sa'id Sa'ad bin Malik bin Sinan al-Khudri radhiyallahu 'anhu bahwa Rasulullah shallallahu 'alaihi wa sallam bersabda, "Tidak boleh membahayakan diri sendiri dan tidak boleh membahayakan orang lain." Hadits hasan, diriwayatkan oleh Ibnu Majah, ad-Daraquthni, dan selain keduanya dengan sanadnya, serta diriwayatkan pula oleh Malik dalam al-Muwaththa' secara mursal dari Amr bin Yahya dari ayahnya dari Nabi shallallahu 'alaihi wa sallam tanpa menyebutkan Abu Sa'id, tetapi ia memiliki banyak jalan periwayatan yang saling menguatkan satu sama lain. ${ }^{24}$

Maksud Hadis ini "tidak ada kemudaratan dan tidak boleh memudaratkan," yaitu seseorang tidak boleh merusak dirinya dan orang lain. Tidak boleh memulai berbuat kerusakan atau membalas dengan kerusakan. Apabila kerusakan dan perbuatan merusak dilarang, kemaslahatan dan kesejahteraan akan terjaga dan terpelihara. Dari hadis ini, ada ulama berkesimpulan bahwa pada prinsipnya kemudaratan itu haram. Kata mudarat yang dimuat dalam Hadis tersebut berbentuk umum dalam ungkapan peniadaan, dengan demikian yang dimaksud mudarat yaitu berbagai jenis kerusakan. Sedangkan kemaslahatan pada prinsipnya adalah mubah karena itu mencegah kerusakan sangat diperlukan untuk menegakkan kemaslahatan.

Apabila manusia memakan makanan dan meminum minuman yang haram maka akan menimbulkan dampak buruk bagi manusia itu sendiri baik terhadap pribadinya maupun terhadap orang lain atau masyarakat terhadap lingkungannya. Maka peneliti ingin mengemukakan di antara akibat buruk dari makanan dan minuman yang haram adalah:

Pertama: Amal ibadahya tidak akan diterima dan doanya tidak akan dikabulkan Allah Swt.

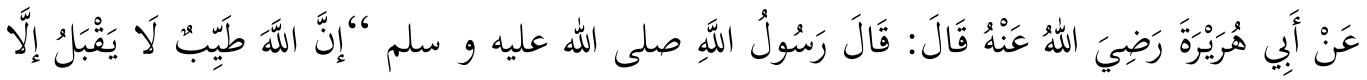

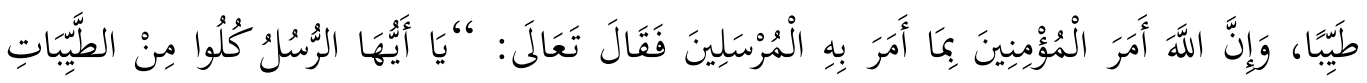

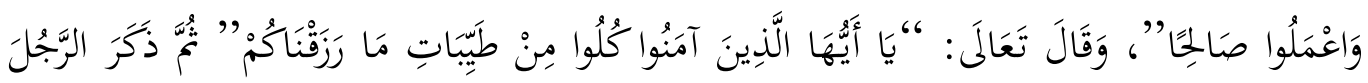

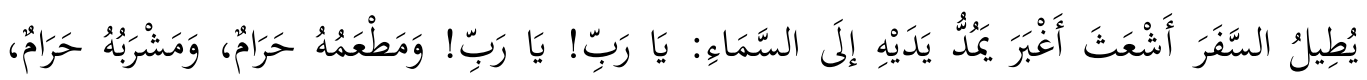

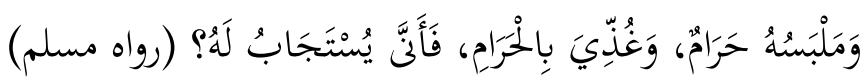

Dari Abu Hurairah t dia berkata, "Rasulullah SAW bersabda "Sesungguhnya Allah Ta'ala Maha Baik, Dia tidak menerima kecuali yang baik. Dan sesungguhnya Allah memerintahkan orang beriman sebagaimana Dia memerintahkan para rasul-Nya dengan berfirman (yang artinya), "Wahai Para Rasul makanlah yang baik-baik dan beramal shalehlah." Dia juga berfirman (yang artinya), "Wahai orang-orang yang beriman makanlah yang baik-baik dari apa yang Kami rizkikan kepada kalian. "Kemudian beliau (Rasulullah SAW) menyebutkan ada seseorang yang melakukan safar dalam keadaan kumal dan berdebu. Dia memanjatkan kedua tangannya ke langit seraya berkata, "Ya

\footnotetext{
${ }^{24}$ Ibid, h.29
} 
Robbku, Ya Robbku," padahal makanannya haram, minumannya haram, pakaiannya haram dan perutnya kenyang dari sesuatu yang haram, maka (jika begitu keadaannya) bagaimana doanya akan dikabulkan." (Riwayat Muslim). ${ }^{25}$

\section{Kedua: Makan dan minuman yang haram dapat membahayakan kesehatan}

\section{Diantaranya}

a. Bangkai: Sesuai dengan Alquran surah al-Mâ'idah (5): 3, al-Baqarah (2): 172-173, al-Mâ'idah (5): 3, dan alAn'âm (6): 145. Bangkai adalah hewan yang mati dengan sendirinya atau hewan yang kematiannya tanpa disembelih secara syar'I menurut Ibn Katsîr pengharaman makan bangkai tidak lain karena pada bangkai terdapat kemudaratan bahaya yaitu darah yang tertahan, tentu ini sangat membahayakan bagi agama dan tubuh, oleh karenanya Allah mengharamkannya. ${ }^{26}$ Yûsuf al-Qaradhawî mencatat lima hikmah dari diharamkannya bangkai.:

- Pertama, fitrah yang sehat menetapkan bahwa ia adalah kotor. Akal pikiran yang normal mengatakan bahwa makan bangkai merendahkan derajat manusia.

- Kedua, seseorang Muslim dibiasakan untuk memiliki maksud dan niat dalam setiap urusannya. Ia tidak memperoleh sesuatu kecuali setelah memantapkan niat dan kehendaknya untuk itu.

- Ketiga, binatang yang mati dengan sendirinya, kemungkinan besar disebabkan karena umurnya sudah tua, atau kecelakaan, atau memakan tumbuhan yang beracun, atau musibah lainnya. Semua itu tidak dapat dijamin keamanannya.

- Keempat, dengan pengharaman bangkai itu atas kita maka Allah hendak memberi kesempatan kepada binatang untuk kita santap sebagai wujud kasih sayang Allah padanya, karena mereka juga umat sebagaimana kita.

- Kelima, agar manusia memelihara binatang yang menjadi miliknya, tidak dibiarkan begitu saja ia sakit, melemah, lalu mati sia-sia. ${ }^{27}$

b. Babi: Dasar yang mengharamkan daging babi adalah Alquran surah al-Baqarah (2): 173, al-Mâ'idah (5): 3, al-An'âm (6): 145, dan al-Nahl (16): 115. Dalam Ahkâm al-Qur'ân, al-Jashshâsh menyatakan ayat-ayat tersebut secara jelas menegaskan keharaman daging babi. Diharamkan dalam nash, adalah hewan kotor, karena salah satu makanan yang paling ia sukai adalah kotoran dan benda-benda najis. Ia adalah hewan yang berbahaya di semua tempat dan benua, terutama di daerah-daerah yang bercuaca panas, sebagaimana dijelaskan dalam sebuah penelitian. Memakan daging babi akan menyebabkan penyakit cacingan yang

${ }^{25}$ Imam Muslim, Shohih Muslim,(Kairo :Darul hadis,2000 ), jilid 2,h.703, No.1015

${ }^{26}$ Abi al-Fida al-Hafzh ibnu Katsir al-Dimasyqi, Tafsir al-Quran al-'Azhim, (Mu'assasah al Risalah, Malik Fahd,2000) h. 11

${ }^{27}$ Yusuf al-Qaradhawi, Al-Halal wal-Haram fil-Islam,(Beirut: Darul fikr,2000) h. 75. 
bisa menyebabkan kematian karena penyakit parasit yang terdapat dalam babi. Lebih dari itu memakan daging babi akan mempengaruhi sifat kesucian dan kemuliaan seseorang. ${ }^{28}$

c. Darah: Ayat-ayat alquran yang menetapkan keharaman darah adalah al-Baqarah (2): 172-173, al-Mâ'idah (5): 3. Analisis kimia terhadap darah menunjukkan bahwa salah satu kandungan darah adalah asam urat (uric acid) yang tinggi. Asam urat merupakan senyawa berbahaya bagi tubuh. Selain itu, darah juga memiliki kandungan zat besi. Kandungan zat besi inilah yang menjadi salah satu alasan darah berbahaya untuk dikonsumsi. Kandungan zat besi yang berlebih dalam tubuh dapat menyebabkan penyakit hemokromatosis. Hemokromatosis merupakan kelainan klinis sebagai akibat kelebihan jumlah keseluruhan zat besi dalam tubuh dan kegagalan fungsi organ akibat keracunan zat besi. Tubuh terlalu banyak menyerap zat besi dari makanan dan kelebihan zat besi disimpan di hati, jantung, dan pankreas Hemokromatosis dapat mengakibatkan penumpukan cairan di paru-paru, gangguan saraf, dehidrasi, dan tekanan darah rendah. ${ }^{29}$

d. Khobaist bermakna segala sesuatu yang merasa jijik untuk memakannya, seperti ular, kelelawar, tikus dan hasyarot (berbagai hewan kecil yang hidup di darat). Ini termasuk dalam kategori haram, karena memakan hewan yang menjijikan ini disebut ilmuwan China sebagai sumber penyebaran virus novel corona, yang berawal dari Pertama kali terditeksi pada Desember 2019 di Wuhan, setelah beberapa orang mengalami pneumonia tanpa sebab yang jelas dan prosedur perawatan serta vaksin yang diberikan ternyata tidak efektif. Diduga berasal dari pasar Huanan dengan kondisi pasar yang basah dan lembab membuat virus corona lebih mudah berpindah baik dari hewan hidup ke hewan mati, begitu pula dari penjualnya yang melakukan kontak langsung dengan hewan ke pembelinya kemudian dari manusia kepada manusia. WHO menamakan virus corona jenis baru ini dengan kode Novel 201 Coronavirus (2019-nCoV). WHO memberikan menyebut virus corona jenis baru ini dengan kode Novel 201 Coronavirus (2019-nCoV). Selain itu, pasar Huanan Wuhan memang dikenal menjual berbagai hewan liar untuk dikonsumsi. Diperkirakan ada lebih dari 112 jenis hewan liar diperdagangkan di pasar ini. Masih dilansir dari kompas (dot) com, diyakini awal penularan virus berasal dari hewan yang diperdagangkan di Pasar Huanan, Wuhan. Berikut beberapa jenis hewan liar dan eksotis yang diduga kuat menjadi asal wabah virus corona yang mematikan tersebut seperti: serigala, rubah, burung merak, unta, burung unta, ular, kelelawar, koala, salamander, dan tikus. Sehingga kelelawar dan ular mendapatkan dugaan paling kuat karena sebelumnya kasus virus SARS yang juga berasal dari China juga ditemukan pertama kali di kedua hewan eksotis ini. Menurut statistik yang dikumpulkan oleh Johns Hopkins University, wilayah ini adalah pusat penyebaran wabah, dengan hampir $82 \%$ dari 75.000 lebih kasus

${ }^{28}$ Imam 'Ali al-Sayis, Tafsir Ayat-ayat Ahkam ,( Jogjakarta:keira publishing ,2010),Jilid1, h. 79

${ }^{29}$ Mulyantari K, Lestari AAW, Subawa AAN, Oka TG, Djelantik S. 2018. Penderita dengan Hemokromatosis Primer. Indones. J. Clin. Pathol. Med. Lab. 18, hal: 141-144 
yang terdata sejauh ini di China dan peneliti juga menemukan bahwa 27 orang dari sampel 41 pasien yang dirawat di rumah sakit pada tahap awal wabah "telah berhubungan dengan kawasan pasar". Hipotesis bahwa wabah dimulai di pasar dan bisa ditularkan dari hewan hidup ke inang manusia sebelum menyebar dari manusia ke manusia masih dianggap sebagai kemungkinan paling besar, menurut Organisasi Kesehatan Dunia (WHO). ${ }^{30}$

\section{Ketiga: Menghalangi setiap individu untuk mengingat Allah SWT}

Sebagaimana dalam firmannya:

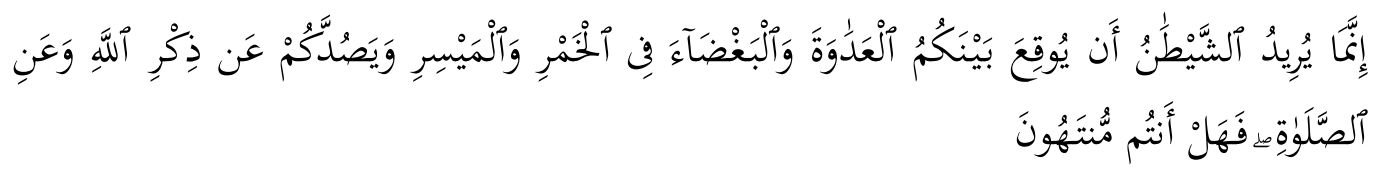

Sesungguhnya syaitan itu bermaksud hendak menimbulkan permusuhan dan kebencian di antara kamu lantaran (meminum) khamar dan berjudi itu, dan menghalangi kamu dari mengingat Allah dan sembahyang; Maka berhentilah kamu (dari mengerjakan pekerjaan itu). QS. Al-Maidah(5): 90.

Pada ayat di atas Allah swt menyebutkan alasan mengapa diharamkan minum khamar dan berjudi bagi orang-orang mukmin. Alasan yang disebut-Nya dalam ayat ini ada dua macam. Pertama karena dengan kedua perbuatan itu setan ingin menimbulkan permusuhan dan rasa saling membenci di antara sesama manusia. Kedua karena perbuatan itu akan melalaikan kita dari mengingat Allah, ini merupakan salah satu tipu daya setan yang bertujuan agar umat manusia terjerumus dalam hal yang diharamkan Allah SWT seperti makanan haram sehingga dapat menghalangi umat manusia untuk mengingat Allah, melupakan zikir dengan hati dan lidah, mengabaikan peringatan yang disampaikan oleh Rasulullah SAW, ketika umat manusia terbiasa melupakan zikir dari sisi rububiyyah (pemeliharaan) Allah kepada manusia maka hal ini akan mengantarkan manusia untuk melupakan sisi 'ubudiyyah (ibadah) kepada-Nya.

Dan jika dampak corona telah terjadi pada negeri ini, sebaiknya mengingat lagi nasehat dari sabda Nabia Muhammad SAW kepada kita semua sebagai berikut:

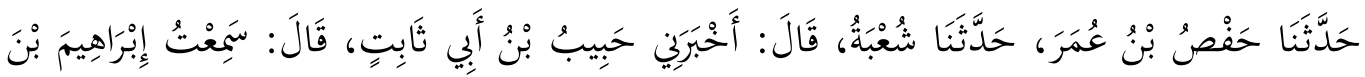

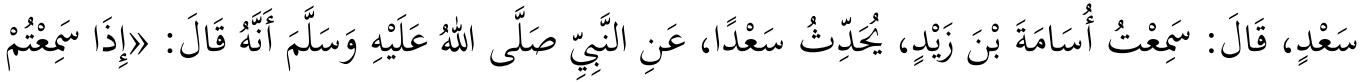

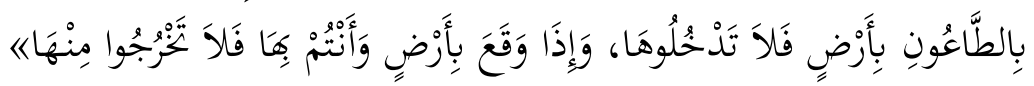

"Menceritakan kami Hafash bin Umar, Menceritakan kami Syu'bah, Berkata: Mengabarkan aku Habib bin abi tsabit berkata,aku mendengar Ibrahim bin sa'd berkata: Aku mendengar Usamah bin Zaid menceritakan kepada Sa'd, Dari Nabi SAW bersabda:

"Apabila kalian mendengar wabah lepra di suatu negeri, maka janganlah kalian masuk

\footnotetext{
${ }^{30}$ https://www.bbc.com/indonesia/majalah-51999550
} 
ke dalamnya, namun jika ia menjangkiti suatu negeri, sementara kalian berada di dalamnya, maka janganlah kalian keluar dari negeri tersebut." (HR:Bukhori). ${ }^{31}$

\section{Kesimpulan}

Segala jenis makanan apa saja yang ada di dunia halal untuk dimakan sampai ada dalil yang melarangnya. Makanan yang enak dan lezat belum tentu baik untuk tubuh, dan boleh jadi makanan tersebut berbahaya bagi kesehatan. Selanjutnya makanan yang tidak halal bisa mengganggu kesehatan rohani. Daging yang tumbuh dari makanan haram, akan dibakar di hari kiamat dengan api neraka.

Ada banyak ayat Alquran yang berbicara tentang makanan halal dan makanan haram, Makanan yang halalan thoyyibah atau halal dan baik serta bergizi tentu sangat berguna bagi kita, baik untuk kebutuhan jasmani dan rohani. Makanan dan minuman haram, selain dilarang oleh Allah SWT, juga mengandung lebih banyak mudharat (kejelekan) daripada kebaikannya.

Maka dari itu, pemahaman dan pengetahuan kepada ketentuan syariah mengenai halal, haram, dan syubhat yang berlandaskan Alquran dan Hadis serta pendapat para fuqoha amat penting dan menjadi panduan penting untuk selalu berada dalam koridor halal. Kembali kepada yang ditetapkan Allah SWT serta mematuhi atas batasan koridor hukum agar tidak terjadi hal- hal yang tidak diinginkan seperti munculnya wabah virus, bakteri yang membahayakan, merusak bahkan mematikan, sehingga mempengaruhi dampak buruk bagi setiap elemen kehidupan secara global.

\section{Referensi:}

Abd al-Rahmân ibn Ma'la , (Mu'assasah al-Risalah, Malik Fahd, 1420H-2000H), Cet. I

Abd al-Rahmân ibn Nashir ibn al-Sa'di, Taysir al-Karim al-Rahman Tafsir Kalm alMannân, di-tahqiq oleh

Abi al-Fida al-Hafzh ibnu Katsir al-Dimasyqi, Tafsir al-Quran al-'Azhim, Mu'assasah al Risalah, Malik Fahd,2000.

Abu al-Sa'ud Muhammad ibn Muhammad ibn Musthafa alImadi, Mufradat al-Quran, versi Maktabah asy Syamilah

Abu Ja"far Muhammad bin Jarir Ath-Thabari, Tafsir Ath-Thabari, Jakarta: Pustaka Azzam, 2008.

Abu Muhammad al-Husayn ibn Mas'ûd al-Baghawî, Ma'âlim Tanzîl, Dâr Tibah, Majma' Mâlik Fahd, 1417H-1997 M, Cet. IV, jilid I.

Abu Zakariya Yahya bin Syaraf an-Nawawi ad-Dimasqi, Matan Arba'in Nawawi,Surabaya : Pustaka Syabab,2007.

\footnotetext{
${ }^{31}$ Imam Bukhori, Shohih Bukhari,( Jakarta: Ummulqura, 2009), Jilid 7, h.130, No: 5287
} 
Aji, A.M.; Yunus, N.R. Basic Theory of Law and Justice, Jakarta: Jurisprudence Institute, 2018.

Al-Qur"an dan Terjemahnya Departemen Agama RI, op.cit.

Buana, Dana Riksa, "Analisis Perilaku Masyarakat Indonesia dalam Menghadapi Pandemi Virus Corona (Covid-19) dan Kiat Menjaga Kesejahteraan Jiwa," Salam: Jurnal Sosial dan Budaya Syar-i, Volume 7, No. 3 (2020).

HAMKA, Tafsir Al-Azhar, Jakarta: Gema Insani, 2015.

Imam ‘Ali al-Sayis, Tafsir Ayat-ayat Ahkam ,Jogjakarta:keira publishing ,2010.

Imam al-Syawkânî, Fath al-Qâdir, Bayrût: Dâr al-Ma'rifah, 2007.

Imam Baihaqi , Assunan ash-shoghir,jilid4,Beirut:Darul Fikr, 2000

Imam Bukhori, Shohih Bukhari,( Jakarta: Ummulqura, 2009) ,Jilid 7, , h.130,No: 5287

Imam Nawawi, Matan Arba'in Nawawi,Jakarta : Pustaka Ibnu Umar,2003.

M. Quraish Shihab, Tafsir Al-Misbah; Pesan, Krsan dan Keserasian al-Qurean, Jakarta: Lentera Hati, 2002

Maggalatung, A.S.; Aji, A.M.; Yunus, N.R. How The Law Works, Jakarta: Jurisprudence Institute, 2014.

Muhammad ibn Jarîr ibn Yazîd ibn Katsîr ibn Ghâlib al-Amalî Abû Ja' far al-Tabârî, Jâmi' al-Bayân fî Ta' wîl al-Qur'ân, di-tahqîq oleh Ahmad Muhammad Syakir, Penerbit Mu'assasah al-Risâlah, cetakan Malik Fahad, 2000.

Muhammad ibn Jarîr ibn Yazîd ibn Katsîr ibn Ghâlib al-Amalî Abû Ja'far al-Tabari, Jami' al-Bayân f Ta'wil al-Qur'ân.

Muhammad Rawas Qal'ajî dan Muhammad Shâdiq Qanaybî, Mu'jam Lughah alFuqaha, Bayrût: Dâr al-Fikr, 1405H-1985M.

Mulyantari K, Lestari AAW, Subawa AAN, Oka TG, Djelantik S. 2018. Penderita dengan Hemokromatosis Primer. Indones. J. Clin. Pathol. Med. Lab. 18.

Rohmah, S.N. "Adakah Peluang Bisnis di Tengah Kelesuan Perekonomian Akibat Pandemi Corona?," Adalah: Volume. 4, No. 1 (2020)Q.

Sayyid Qutub, Tafsir fi Zhilalil Qur"an, jilid I, Jakarta: Gema Insani, 2000.

Syaikh Ahmad Syakir, Tafsir Ibnu Katsir, Jakarta: Darus Sunnah, 2014.

Yunus, N.R.; Anggraeni, RR Dewi.; Rezki, Annissa. "The Application of Legal Policy Theory and its relationship with Rechtsidee Theory to realize Welfare State," 'Adalah, Volume 3, No. 1 (2019)

Yunus, N.R.; Rezki, Annissa. "Kebijakan Pemberlakuan Lock Down Sebagai Antisipasi Penyebaran Corona Virus Covid-19," Salam: Jurnal Sosial dan Budaya Syar-i, Volume 7, No. 3 (2020).

Yûsuf al-Qaradhâwî, Al-Halâl wa al-Harâm f al-Islâm, terjemah Wahid Amadi dkk, Halal Haram dalam Islam, Solo: Era Intermedia, 1424H-2003 M, Cet III. 
Faiqatul Husna

Zulaekah S, Kusumawati Y. Halal dan haram makanan dalam islam. SUHUF, Vol. XVII, No. 01/Mei 2005.

https://www.itb.ac.id/files/focus/2020-01-

25PedomanKesiapsiagaanNovelCoronaVirus3.pdf

https://www.bbc.com/indonesia/majalah-51999550 


\section{Indexed by :}
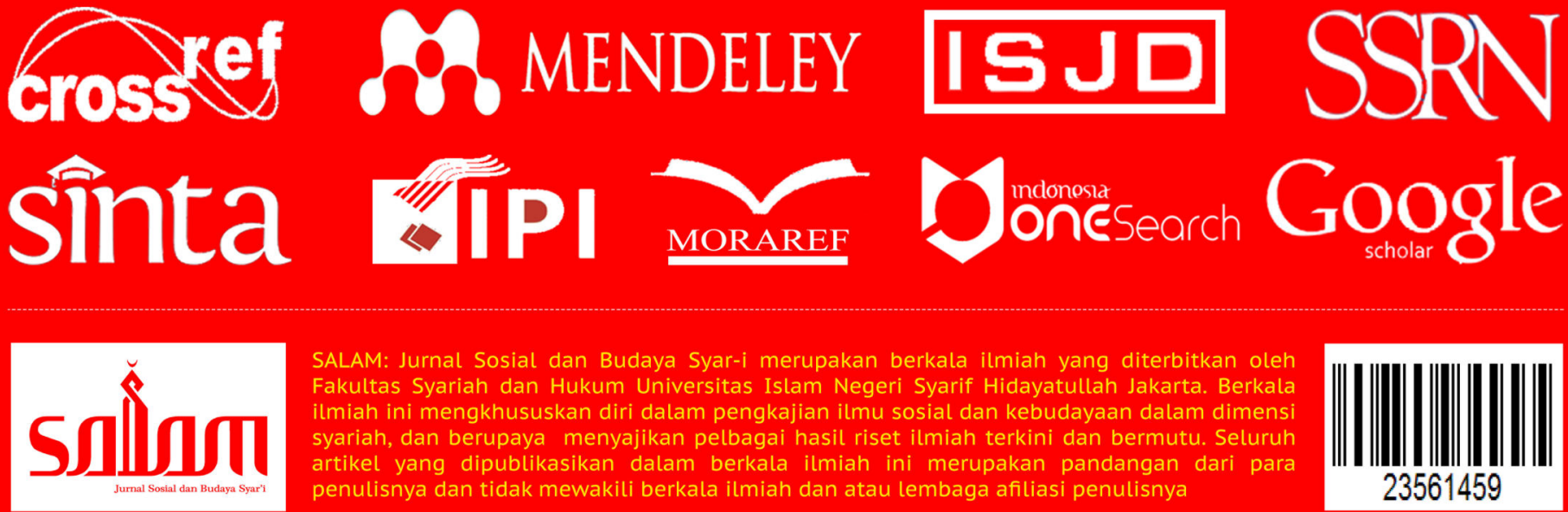

SALAM: Jurnal Sosial dan Budaya Syar-i merupakan berkala ilmiah yang diterbitkan oleh Fakultas Syariah dan Hukum Universitas Islam Negeri Syarif Hidayatullah Jakarta. Berkala ilmiah ini mengkhususkan diri dalam pengkajian ilmu sosial dan kebudayaan dalam dimensi syariah, dan berupaya menyajikan pelbagai hasil riset ilmiah terkini dan bermutu. Seluruh artikel yang dipublikasikan dalam berkala ilmiah ini merupakan pandangan dari para penulisnya dan tidak mewakili berkala ilmiah dan atau lembaga afiliasi penulisnya

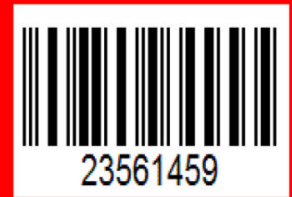

